\title{
Az anyagiasság és a személyes jóllét kap- csolata: a nyugati fogyasztói társadalom egy árnyoldala
}

\author{
Erdös Sándor \\ Pécsi Tudományegyetem
}

\begin{abstract}
A KUTATÁS CÉLJA
A dolgozat abba az 1980-as évek közepe óta tartó tudományos diskurzusba kapcsolódik be, mely az anyagiasság és az egyének személyes jólléte közötti kapcsolatot vizsgálja. A tanulmány célja, hogy rámutasson, az anyagiasság, mint gondolkodásmód, milyen kapcsolatban áll az egyének személyes jóllétével. A dolgozat így a nyugati fogyasztói társadalom lehetséges árnyoldalaira kíván rávilágítani.
\end{abstract}

\begin{abstract}
ALKALMAZOTT MÓDSZERTAN
Vizsgálatunkat egy kérdőíves felmérésből származó, 1819 megfigyelésből álló, demográfiai jellemzők tekintetében országosan reprezentatív mintán végeztük. Az elemzésbe bevont változók esetében a kérdőíves kutatások során felmerülő potenciális torzítások hatását kezeltük. A vizsgálatban kiemelt szerepet betöltő anyagiasság változót a gazdagság és pénz személyes értékrendben betöltött relatív helyzetével közelítettük, míg a személyes jóllétet az élettel való elégedettség és az önbecsülés mintaátlagtól vett eltérésével mértük. A változók közötti kapcsolatok becslésére OLS-regressziót alkalmaztunk.
\end{abstract}

\section{LEGFONTOSABB EREDMÉNYEK}

A materialista értékek előtérbe helyezése irracionálisnak tünik, tekintve, hogy az anyagias célokra való túlzott fókuszálás alacsonyabb személyes jólléttel párosul. Habár a személyes jóllétnek mind objektív, mind szubjektív, illetve társadalmi és környezeti tényezők is részét képezik, eredményeink szerint a materialista gondolkodásmód, továbbá a materialista értékeket hangsúlyozó fogyasztói kultúra követése már az egyén szintjén problémákat eredményezhet.

\section{GYAKORLATI JAVASLATOK}

A materialista értékek előtérbe helyezése irracionálisnak tünik, tekintve, hogy az anyagias célokra való túlzott fókuszálás alacsonyabb személyes jólléttel párosul. Habár a személyes jóllétnek mind objektív, mind szubjektív, illetve társadalmi és környezeti tényezők is részét képezik, eredményeink szerint a materialista gondolkodásmód, továbbá a materialista értékeket hangsúlyozó fogyasztói kultúra követése már az egyén szintjén problémákat eredményezhet.

Kulcsszavak: materializmus, anyagiasság, jóllét, személyes jóllét, élettel való elégedettség, önbecsülés

Köszönetnyilvánitás: A szerző köszönetét fejezi ki Törőcsik Máriának és Takács Andrásnak, akik ösztönzése nélkül a tanulmány nem készült volna el, valamint Kehl Dánielnek és Nagy Ákosnak, akik értékes megjegyzéseket füztek a munkához. Emellett köszönet Riedelmayer Bernadettnek, aki hasznos technikai segítséget nyújtott a munka során.

DOI: 10.15170/MM.2021.55.01.04 


\section{BEVEZETÉS INTRODUCTION}

Az 1980-as évek közepétől a fogyasztáskutatók és pszichológusok elkezdtek azzal foglalkozni, hogy az anyagias értékek elötérbe helyezése miként hat az egyénre (Belk 1988, Richins és Dawson 1992). Azóta számos tudományos igényü munka született a témában (lásd például Dittmar et al. (2014) metaanalízisét, vagy Debreceni (2018) 2010 után írt tanulmányokról szóló összefoglaló munkáját) melyek mind arra jutottak, hogy az anyagias célokat jobban elötérbe helyező egyének én-központúak, életük bonyolultabb, összetettebb, hajlamosak a depresszióra vagy a szorongásra, közömbösek a közösséget, vagy társadalmat érintő kérdéseket illetően, és általában elégedetlenebbek az életükkel. Ezzel szemben az életükkel elégedettebb egyéneknek több barátjuk van, nyitottak, optimisták, családi helyzetük rendezettebb, többet foglalkoznak a közösség problémáival, és elkötelezettebbek (Richins és Dawson 1992, Kasser 2016).

Debreceni (2018) a 2010 óta megjelent, anyagiassággal foglalkozó tanulmányokat három fó kategóriába sorolta: (i) az anyagiasság és a különböző fogyasztói szokások közötti összefüggéseket feltáró munkák, (ii) a materialista értékek erősödését okozó háttérváltozók vizsgálatával foglalkozó tanulmányok, (iii) és az anyagias attitüd személyes jóllétre, boldogságra és az élettel való elégedettségre gyakorolt hatását feltáró kutatások. Jelen dolgozat az utóbbi kategóriához tartozó eredményeket kívánja bővíteni. A dolgozat célja tehát, hogy rámutasson, az anyagiasság, mint gondolkodásmód, miként hat az egyének személyes jóllétére. A dolgozat a fejlett társadalmakban egyre inkább megfigyelhető problémák jobb megértéséhez járul hozzá, és rávilágít a nyugati fogyasztói társadalom lehetséges árnyoldalaira.

\section{ALAPVETŐ DEFINÍCIÓK TISZTÁZÁSA \\ CLARIFICATION OF BASIC DEFINITIONS}

A dolgozat központi kérdése, hogy az anyagiasság és az egyén személyes jólléte között milyen kapcsolat figyelhető meg. Előbbi fogalomra a kezdetekben úgy tekintettek, mint tulajdonságra, ami elválaszthatatlan az ember személyiségétől (Belk, 1984), később azonban már úgy definiálták, mint egy gondolkodásmód, mely determinálja a tárgyak szerzésére és birtoklására irányuló magatartást (Richins és Dawson 1992). Az anyagiasságra jellemző a vagyon és a javak birtoklásának sikerrel és boldogsággal, valamint magasabb társadalmi státusszal és teljesítménnyel való párosítása, az anyagi javak felhalmozására irányuló viselkedés, az irigység és önzőség, továbbá a pénz és birtoklás fontosságának hangsúlyozása az életben megjelenő más célok elérésében (Moldes \& Ku 2020). Jelen tanulmányban azt az egyént tekintjük anyagiasnak, aki olyan értékeket, célokat fogad el és követ, melyek a pénzszerzésre, annak fontosságára, a birtoklásra és az anyagi javak felsőbbrendűségére vonatkoznak.

A vizsgálat másik központi fogalma a jóllét. Ahogy Kelemen és Kincses (2015) rámutattak, a jóllét egy multidimenzionális jelenség, mely egy időben változó állapotot fejez ki, és amelyre objektív és szubjektív, illetve egyéni és társadalmi tényezők egyaránt hatással vannak. Nem meglepő, hogy nem alakult ki egy általánosan elfogadott meghatározása. Lee és Ahn (2016) úgy fogalmazott, hogy a jóllét önmagában egy személy vagy csoport állapotának az általános kifejezése különböző kontextusokban, mint például pszichológiai, fizikai, vagy gazdasági állapot. Ezen belül a személyes jóllét az egyén saját helyzetének értelmi és érzelmi alapú megítélése (Debreceni 2018). Az egyének jólléti állapotát az egyes tanulmányok igen eltérően próbálták közelíteni, melyeket Dittmar et al. (2014) négy széles kategóriába sorolt: (i) az első kategória a szubjektiv jóllét, ahol az egyén élettel való elégedettségét, illetve a pozitív élmények gyakoriságának az érzékelését vizsgálták. (ii) Második kategória az önbecsülés, ahol a vizsgálatok az egyén önmagára vonatkozó pozitív és negatív megítélését próbálták feltárni. (iii) A harmadik kategóriába azokat a tanulmányokat sorolták a szerzők, melyek a mentális állapotból - pl. depresszió, szorongás, vagy kényszeres vásárlási szokások - következtettek az egyén jóllétére. (iv) A negyedik kategóriába tartozó kutatások a fizikális állapot felmérésére például fejfájás, hasfájás gyakorisága -, vagy az egészségre káros szokások - pl. alkoholfogyasztás, dohányzás - feltárására koncentráltak. 


\section{ANYAGIASSÁG ÉS A JÓLLÉT KAPCSOLATA \\ THE RELATIONSHIP BETWEEN MATERIALISM AND WELL- BEING}

Számos tanulmány vizsgálta a materialista értékrend és a szubjektív jóllét közötti kapcsolatot és általánosságban arra a következtetésre jutottak, hogy a kapcsolat negatív és robusztus mind keresztmetszeti, mind longitudinális adatokon végzett elemzések esetében. A keresztmetszeti vizsgálatok rámutattak, hogy az anyagiasabb egyének összeségében elégedetlenebbek az életükkel (Brown \& Kasser 2005), hajlamosabbak a depresszióra, a szorongásra, a kényszeres vásárlói viselkedésre (Kim et al. 2003, Dittmar \& Kapur 2011), valamint jobban eladósodnak (Nepomuceno és Laroche 2015), mint a kevésbé anyagias egyének. A longitudinális vizsgálatok európai, amerikai és ázsiai mintán is arra a következtetésre jutottak, hogy az egyének anyagiasságának a csökkenése a személyes jóllétük növekedésével párosul (Hellevik 2003, Twenge et al. 2010, Wang et al. 2017). Kasser et al. (2014) kétéves periódust figyelembe véve szintén azt találták, hogy az anyagiasságra fektetett hangsúly csökkenése a szubjektív jóllét növekedésével párosul. Úgy tủnik tehát, hogy minél inkább materialista értékeket követ egy egyén, annál kisebb megelégedettséget fog tapasztalni az életben.

Abban a széleskörü szakirodalomban, mely negatív kapcsolatot talált az anyagiasság és a jóllét között, három elméleti magyarázat különíthető el: (i) a tényleges és a vágyott anyagi helyzet közötti eltérés állandó elégedetlenségforrás (Schor, 1999), (ii) az anyagiasság pszichológiai bizonytalanságra vezethető vissza (Kasser et al. 1995, Rindfleisch et al. 1997, Sheldon \& Kasser, 2008), (iii) öndeterminációs elmélet - self-determination theory (SDT) (Deci \& Ryan, 2000).

\section{ADATOK, VÁLTOZÓK ÉS HIPOTÉZISEK DATA, VARIABLES AND HYPOTHESES}

Vizsgálatunkban egy 2018-as, 2000 főt érintő kérdőíves felmérésre támaszkodtunk. A felhasznált adatok demográfiai jellemzők tekintetében országosan reprezentatív mintának tekinthetők. Azok a megfigyelések, melyek esetében a vizsgálatban fel- használt itemnél hiányzó értéket - a válaszadó nem adott választ - találtunk, kikerültek az elemzésből. Az így kapott 1819 elemủ minta szintén reprezentatív nem, kor, régió, végzettség és lakóhely településtípusa szerint.

A materializmus mérésére számos megoldás született a múltban, melyek közül az anyagiasság kutatásokat leginkább Belk (1984), illetve Richins \& Dawson (1992) (MVS) materializmus mércéje, valamint Kasser \& Ryan (1993) aspirációs indexe (AI) határozta meg. Dittmar et al. (2014) a materializmus skálák két típusát különböztették meg: abszolút és relatív mértékek. Mind a két típus esetében megtalálhatók a pénz, vagyon, vagy jövedelem jelentőségét feltáró, egyedi itemeket alkalmazó eljárások - ezek az ún. rövidebb materializmus mércék -, illetve a komplexebb, az anyagiasságot több szempontból jellemző mérések. Általánosságban elmondható, hogy a rövidebb materializmusmércék az anyagiasság és a jóllét közötti kapcsolatot kevésbé képesek megragadni. Ez alól kivételt képez az a megoldás, mely a pénz, vagy vagyon egyéni értékrendben betöltött relatív fontosságát méri. Utóbbi megállapítás abból is következik, hogy az abszolút mértékek egyértelmủen gyengébb kapcsolatot mutatnak a jólléttel.

A személyes jóllét a materializmushoz hasonlóan számos módon megragadható, tekintve, hogy ez a dimenzió is elvont jelentéstartalommal bír. Mint már érintettük a személyes jóllét fogalomkörébe beletartozhat az egyén élettel való megelégedettsége, a pozitív érzelmeinek gyakorisága, az önbecsülés, az aktuális mentális, vagy fizikális állapot, illetve az egyénre jellemző különböző fogyasztói magatartások.

Tekintve, hogy a materializmus mércék esetében a relatív mutatók jobban képesek megragadni a kapcsolatot, továbbá mivel a pénz és a gazdagság bármely anyagiasság megközelítés központi eleme, ezért az anyagiasság ismérvet a gazdagság és pénz személyes értékrendben betöltött relatív helyzetével mértük. A válaszadóknak a következő kérdésre kellet választ adniuk: Mennyire tartja fontosnak az alábbi tulajdonságokat? Gazdagság, pénz. Véleményét kérjük, hatfokozatú skálán fejezze ki, ahol az 1 azt jelenti, hogy egyáltalán nem tartja fontosnak, a 6 pedig azt jelenti, hogy nagyon fontosnak tartja az adott szempontot! Mivel nem a válaszok abszolút értékére voltunk kíváncsiak, hanem annak az egyéni értékrendben betöltött relatív helyzetére, ezért az említett kérdésre adott választ a hatfokozatú skálán adott többi tényező átlagához viszonyítva határoztuk meg. Ennek az eljárásnak egyik fő előnye, hogy általa a kérdőíves kutatások során felmerülő potenciális torzítások kiküszöbölhetők, 
főként a beleegyező válaszadói torzítás hatása csökkenthető (Hornyák és tsai 2014). Az anyagiasság változónkat ezért a következők szerint határoztuk meg:

$$
\text { Anyagiasság }_{i}=G P_{i}-\frac{1}{m} \sum_{j=1}^{m} X_{j},
$$

ahol, az Anyagiasság $_{i}$ az $i$-edik válaszadó számított anyagiasság-mértéke, a $G P_{i}$ válaszadó válasza, míg $1 / m \sum_{j=1}^{m} X_{j}$ kifejezés a hatfokozatú skálán mért ismérvek számtani átlaga. A mutató esetében a magasabb értékek azt jelentik, hogy a gazdagság és pénz fontosabb az egyén értékrendjében, relatíve más tényezőkhöz.

A személyes jóllét dimenzió esetében egyrészről arra voltunk kíváncsiak, hogy a válaszadók mennyire elégedettek életükkel. Az élettel való elégedettséget a következő kérdéssel vizsgáltuk: Mennyire elégedett a jelenlegi életével? Kérjük, egy tízfokozatú skála segítségével adja meg, ahol 1 jelenti, hogy egyáltalán nem, 10 pedig, hogy nagyon elégedett! Ezt a változót sem abszolút értéken vettük figyelembe, hanem az egyes válaszadóknak, a minta átlagos elégedettségétől vett távolsága szerint. Erre két okból volt szükség. Egyrészről a mintában az említett kérdésre adott válaszok egy szük intervallumban koncentrálódtak, másrészről pedig azt szándékoztuk feltárni, hogy az anyagiasabb egyének elégedetlenebbek-e életükkel kevésbé materialista társaikhoz képest. Az elégedettséget

$$
\text { Elégedettség }_{i}=\text { ÉVE }_{i}-\frac{1}{n} \sum_{i=1}^{n} \text { ÉVE }_{i}
$$

tehát a következők szerint határoztuk meg:

Az É $V E_{i}$ az $i$-edik válaszadó tízfokozatú skálán elhelyezett pontszáma az élettel való elégedettséghez kapcsolódóan, az $1 / m \sum^{n} E E_{i}$ kifejezés pedig a sokaság átlagos elégedettségét jelöli. A magasabb érték azt jelenti, hogy a válaszadó a többi válaszadóhoz képest elégedettebb életével.

A becslések során a személyes jóllét nagyságát mérni szándékozó második változónk az önbecsülés volt, melyet a következő kérdéssel közelítettünk: Mennyire ért egyet az alábbi állitásokkal? Elégedett vagyok magammal. Jelölje az 1-et, ha az adott állitással egyáltalán nem ért egyet, mig az 5-öt, ha teljes mértékben egyetért! Az élettel való elégedettséghez hasonlóan, itt is a mintában szereplő többi megfigyelés átlagához viszonyítva vettük figyelembe az egyes válaszokat:

$$
\text { Önbecsülés }_{i}=\text { ÖB }_{i}-\frac{1}{n} \sum_{i=1}^{n} \text { ÖB }_{i}
$$

Az Ö $B_{i}$ az $i$-edik válaszadó ötfokozatú skálán elhelyezett pontszáma, az $1 / n \sum_{i=1}^{n} \bar{o} B_{i}$ kifejezés pedig a minta átlagos önbecsülését jelöli. A magasabb önbecsülés érték azt jelenti, hogy a válaszadónak nagyobb az önbecsülése a többi megfigyeléshez viszonyítva.

Végül arra is kíváncsiak voltunk, hogy az anyagiasság milyen kapcsolatban van az anyagi lehetőségek területén érzékelt hátránnyal attól függően, hogy az egyén milyen anyagi helyzetben van. Ennek teszteléséhez jó megoldásnak kínálkozik az anyagi hátrány ismérv vizsgálata, melyet a következő kérdéssel mértünk: Mennyire ért egyet az alábbi állitásokkal? Hátrányban vagyok az anyagi lehetöségeim miatt. Jelölje az 1-et, ha az adott állitással egyáltalán nem ért egyet, mig az 5-öst, ha teljes mértékben egyetért! A kérdőív egyéb területeken - kor, megjelenés, testi adottság, kapcsolatok, nem - érzékelt hátrányokra is rákérdezett, így e független változónál nem arra kerestük a választ, hogy az egyén mennyiben tért el a sokaságra jellemző átlagtól, hanem azt, hogy az anyagi lehetőségek hiányát a többi területhez viszonyítva mennyire éli meg negatívan, vagy pozitívan:

$$
\text { Anyagi hiányérzet }_{i}=A L H_{i}-\frac{1}{m} \sum_{j=1}^{m} X_{j} \text {, }
$$

ahol, $A L H_{i}$ az anyagi lehetőségek területén érzékelt hátrányra adott pontszám, míg $1 / m \sum_{j=1}^{m} X_{j}$ az ötfokozatú skálán mért, érzékelt hátrányokra vonatkozó válaszok számtani átlaga. A magasabb érték itt azt jelenti, hogy a válaszadó jobban érzékeli az anyagi lehetőségek hiányát, más területhez viszonyítva.

Összegezve az előbbiekben tárgyaltakat a következő hipotéziseket állítottuk fel:

Hipotézis 1a: Az anyagiasság személyes értékrenden belüli fontossága negatív kapcsolatban áll az egyének másokhoz viszonyitott jóllétével.

Hipotézis 1b: Azon egyének esetében, akiknek az anyagiasság fontosabb szerepet tölt be az értékrendjükben az önbecsülésük alacsonyabb másokhoz viszonyitva.

Hipotézis 2a: Az anyagiasabb egyének az anyagi lehetöségek hiányát hátrányosabbnak érzékelik, feltéve, hogy a depriváció nem valós.

Hipotézis 2b: Az anyagi nélkülözésben élök között a materialistább egyének hátrányosabbnak itélik meg az anyagi lehetőségek hiányát. 
A következőkben felvázolásra kerülő modellekben az előbbiekben már bemutatott ismérvek mellett kontrollváltozóként a kérdezett neme, életkora, (hét kategóriában mért) iskolai végzettsége, (öt kategóriában mért) családi állapota, szubjektív egészségi állapota (három kategóriában mérve), és a háztartás megítélt anyagi helyzete (öt kategóriában mérve) szerepel. A változók közötti kapcsolatok becslésére OLS-regressziót alkalmaztunk, a változók között tehát lineáris kapcsolatot feltételeztünk. Ezen felül a vizsgálatunkban a változók folytonosságának a feltételezésével éltünk. A változók leíró statisztikái a Függelékben található A1 táblázatban olvashatók.

\section{EREDMÉNYEK RESULTS}

\section{Anyagiasság és az élettel való elégedett- ség kapcsolata \\ The relationship between materialism and life satisfaction}

Az élettel való elégedettség és az anyagiasság mértéke közötti kapcsolatot feltáró négy regresszió eredményei az 1. táblázatban találhatók.

1. táblázat: Az anyagiasság és az élettel való elégedettség kapcsolata

Table 1. The relationship between materialism and life satisfaction

\begin{tabular}{|c|c|c|c|c|}
\hline & \multicolumn{4}{|c|}{ Eredményváltozó: } \\
\hline & \multicolumn{4}{|c|}{ Élettel való elégedettség } \\
\hline & (1) & (2) & (3) & (4) \\
\hline \multirow[t]{2}{*}{ Anyagiasság } & $-0,200^{* * *}$ & $-0,150^{* * *}$ & $-0,193 * * *$ & $-0,239 * * *$ \\
\hline & $(0,044)$ & $(0,054)$ & $(0,048)$ & $(0,048)$ \\
\hline \multirow[t]{2}{*}{ Érzékelt társadalmi megitélés (dummy) } & & $-0,323 * * *$ & & \\
\hline & & $(0,095)$ & & \\
\hline \multirow[t]{2}{*}{ Érzékelt társadalmi megítélés } & & & $-0,162 * * *$ & \\
\hline & & & $(0,039)$ & \\
\hline \multirow[t]{2}{*}{ Anyagi helyzet (dummy) } & & & & $0,922 * * *$ \\
\hline & & & & $(0,189)$ \\
\hline \multirow[t]{2}{*}{ Anyagiasság*Tsd-i megítélés (dummy) } & & $-0,071$ & & \\
\hline & & $(0,093)$ & & \\
\hline \multirow[t]{2}{*}{ Anyagiasság*Tsd-i megítélés } & & & $-0,047$ & \\
\hline & & & $(0,036)$ & \\
\hline \multirow[t]{2}{*}{ Anyagiasság*Anyagi helyzet (dummy) } & & & & 0,089 \\
\hline & & & & $(0,163)$ \\
\hline \multirow[t]{2}{*}{ Kor } & $-0,011^{* * *}$ & $-0,010^{* * *}$ & $-0,011 * * *$ & $-0,012 * * *$ \\
\hline & $(0,004)$ & $(0,004)$ & $(0,004)$ & $(0,004)$ \\
\hline
\end{tabular}




\begin{tabular}{|c|c|c|c|c|}
\hline & \multicolumn{4}{|c|}{ Eredményváltozó: } \\
\hline & \multicolumn{4}{|c|}{ Élettel való elégedettség } \\
\hline & (1) & (2) & (2) & (2) \\
\hline \multirow[t]{2}{*}{ Nem (nö) } & $0,213 * *$ & $0,200 * *$ & $0,194 * *$ & $0,170^{*}$ \\
\hline & $(0,092)$ & $(0,092)$ & $(0,092)$ & $(0,097)$ \\
\hline \multirow[t]{2}{*}{ Elvált } & $-0,106$ & $-0,116$ & $-0,116$ & $-0,251$ \\
\hline & $(0,190)$ & $(0,189)$ & $(0,189)$ & $(0,199)$ \\
\hline \multirow[t]{2}{*}{ Özvegy } & $-0,143$ & $-0,143$ & $-0,136$ & $-0,210$ \\
\hline & $(0,238)$ & $(0,237)$ & $(0,237)$ & $(0,249)$ \\
\hline \multirow[t]{2}{*}{ Élettársi kapcsolatban él } & $0,327 * *$ & $0,316^{* *}$ & $0,316^{* *}$ & $0,376^{* *}$ \\
\hline & $(0,149)$ & $(0,149)$ & $(0,149)$ & $(0,157)$ \\
\hline \multirow[t]{2}{*}{ Házas } & $0,323 * *$ & $0,329^{* *}$ & $0,331^{* *}$ & $0,405^{* * *}$ \\
\hline & $(0,141)$ & $(0,141)$ & $(0,141)$ & $(0,148)$ \\
\hline \multirow{2}{*}{$\begin{array}{l}\text { Egészségi állapota némiképp korlátozza az } \\
\text { életvitelben }\end{array}$} & 0,115 & 0,142 & 0,121 & 0,385 \\
\hline & $(0,260)$ & $(0,259)$ & $(0,259)$ & $(0,272)$ \\
\hline \multirow[t]{2}{*}{ Teljesen egészséges } & $1,002 * * *$ & $1,042 * * *$ & $1,036^{* * *}$ & $1,463 * * *$ \\
\hline & $(0,257)$ & $(0,257)$ & $(0,256)$ & $(0,268)$ \\
\hline \multirow[t]{2}{*}{ Néha arra se elég, hogy megéljenek belőle } & $1,597^{* * *}$ & $1,649 * * *$ & $1,639^{* * *}$ & \\
\hline & $(0,485)$ & $(0,484)$ & $(0,484)$ & \\
\hline \multirow{2}{*}{$\begin{array}{l}\text { Elegendő, hogy megéljenek, de félretenni } \\
\text { nem tudnak }\end{array}$} & $2,961^{* * *}$ & $3,008 * * *$ & $2,989 * * *$ & \\
\hline & $(0,453)$ & $(0,453)$ & $(0,452)$ & \\
\hline \multirow[t]{2}{*}{ Megélnek, de keveset tudnak félretenni } & $3,804 * * *$ & $3,849 * * *$ & $3,821 * * *$ & \\
\hline & $(0,457)$ & $(0,456)$ & $(0,455)$ & \\
\hline \multirow{2}{*}{$\begin{array}{l}\text { Nagyon jól megélnek, és félre is tudnak } \\
\text { tenni }\end{array}$} & $4,251 * * *$ & $4,312 * * *$ & $4,306^{* * *}$ & \\
\hline & $(0,480)$ & $(0,479)$ & $(0,478)$ & \\
\hline \multirow[t]{2}{*}{ Szakmunkásképző, szakiskola } & $-0,170$ & $-0,158$ & $-0,157$ & 0,126 \\
\hline & $(0,148)$ & $(0,148)$ & $(0,148)$ & $(0,154)$ \\
\hline
\end{tabular}




\begin{tabular}{|c|c|c|c|c|}
\hline & \multicolumn{4}{|c|}{ Eredményváltozó: } \\
\hline & \multicolumn{4}{|c|}{ Élettel való elégedettség } \\
\hline & (1) & (1) & (1) & (1) \\
\hline \multirow[t]{2}{*}{ Szakközépiskolai érettségi } & 0,006 & 0,007 & 0,015 & $0,294 *$ \\
\hline & $(0,158)$ & $(0,158)$ & $(0,157)$ & $(0,164)$ \\
\hline \multirow[t]{2}{*}{ Gimnáziumi érettségi } & 0,072 & 0,055 & 0,061 & $0,482 * * *$ \\
\hline & $(0,179)$ & $(0,178)$ & $(0,178)$ & $(0,185)$ \\
\hline \multirow[t]{2}{*}{ Felsőfokú technikum/OKJ/FOKSZ } & 0,160 & 0,122 & 0,116 & $0,603 * * *$ \\
\hline & $(0,213)$ & $(0,213)$ & $(0,213)$ & $(0,221)$ \\
\hline \multirow[t]{2}{*}{ Föiskolai diploma } & 0,207 & 0,188 & 0,185 & $0,684 * * *$ \\
\hline & $(0,194)$ & $(0,193)$ & $(0,193)$ & $(0,200)$ \\
\hline \multirow[t]{2}{*}{ Egyetemi diploma } & 0,006 & $-0,039$ & $-0,012$ & $0,461 *$ \\
\hline & $(0,259)$ & $(0,259)$ & $(0,259)$ & $(0,270)$ \\
\hline \multirow[t]{2}{*}{ Konstans } & $-3,968 * * *$ & $-3,895^{* * *}$ & $-4,046^{* * *}$ & $-1,378^{* * *}$ \\
\hline & $(0,516)$ & $(0,515)$ & $(0,514)$ & $(0,328)$ \\
\hline Megfigyelések száma & 1.819 & 1.819 & 1.819 & 1.819 \\
\hline R2 & 0,229 & 0,234 & 0,236 & 0,149 \\
\hline Korrigált R2 & 0,221 & 0,225 & 0,227 & 0,141 \\
\hline Becslés standard hibája & $1,874(\mathrm{df}=1799)$ & $1,869(\mathrm{df}=1797)$ & $1,866(\mathrm{df}=1797)$ & $1,968(\mathrm{df}=1801)$ \\
\hline F-próba & $\begin{array}{c}28,097 * * *(\mathrm{df}= \\
19 ; 1799)\end{array}$ & $\begin{array}{c}26,112 * * *(\mathrm{df}= \\
21 ; 1797)\end{array}$ & $\begin{array}{c}26,438^{* * *}(\mathrm{df}= \\
21 ; 1797)\end{array}$ & $\begin{array}{c}18,537 * * *(\mathrm{df}= \\
17 ; 1801)\end{array}$ \\
\hline
\end{tabular}

Megjegyzés: ${ }^{*} p<0,1 ; * * p<0,05 ; * * * p<0,01$; Zárójelben a t-próba értékek találhatók. Függő változó: tízfokozatú skálán mért élettel való elégedettségre adott válasz és a mintában megfigyelhetö átlagos elégedettség különbsége.

Forrás: saját szerkesztés

Az élettel való elégedettség és a bevont kontrollváltozók esetében a személyes jólléthez kapcsolódó irodalmakkal konzisztens eredményeket kaptunk (Dittmar et al., 2014; Kasser, 2016; Debreceni, 2018). A párkapcsolatban élők - élettársi kapocslat, vagy házas - általánosságban elégedettebbek életükkel. Ez alátámasztja azt a magyarázatot miszerint az emberi kapcsolatok jelentős befolyással bírnak a jóllétre (Deci és Ryan, 2000). Nem meglepő, hogy a szubjektív egészségi állapot is fontos szerepet tölt be a jóllét alakulásában. A háztartás anyagi helyzetére vonatkozó változókra kapott paraméterek monoton növekvők, tehát minél jobb anyagi helyzetben van az egyén, annál elégedettebb lesz életével másokhoz viszonyítva. Érdemes megemlíteni emellett, hogy a nők általánosságban véve elégedettebbek életükkel, a kor pedig enyhe, de szignifikáns és negatív kapcsolatot mutat az eredményváltozóval. Az iskolai végzettség esetében nem találtunk egyértelmű eredményeket.

$\mathrm{Az}$ 1. táblázatban látható első regresszió esetében a folytonosként kezelt anyagiasság mértéket alkalmaztuk magyarázóváltozóként a kontrollváltozók mellett. Az általunk alkalmazott materializmus 
mérce szignifikáns és negatív kapcsolatot mutat a másokhoz viszonyított élettel való megelégedettséggel. Azok az egyének tehát, akik értékrendjében a gazdagság és a pénz relatíve fontosabb, a minta átlagos élettel való elégedettségénél kisebb megelégedettségről számoltak be. A saját átlagos választól vett egységnyi eltérés a gazdagság és a pénz tekintetében, a minta átlagos elégedettségéhez viszonyítva 0,2 ponttal kisebb megelégedettséget jelent, minden más tényezőt változatlannak feltételezve.

A második és harmadik regresszió esetében beépítettük a modellbe a következő kérdésre adott válaszokat is: „Mennyire ért egyet a következö állitásokkal? Az anyagi javak birtoklása szerint itél meg a környezetem. Véleményét ötfokozatú skálán jelezze, ahol az 1 azt jelenti, hogy egyáltalán nem ért egyet az állitással, mig az 5 azt jelenti, hogy teljes mértékben egyetért az állitással!’. Ezt a változót az érzékelt társadalmi megitélésnek neveztük el és az anyagiasság mértékhez hasonló módon számítottuk. A második regresszió esetében egy bináris változót hoztunk létre - érzékelt társadalmi megitélés (dummy) - úgy, hogy a pozitív értékeket egyre, a többi értéket nullára kódoltuk, majd a modellt kibővítettük az új és az anyagiasság változó interakciójával. A harmadik regresszióban az érzékelt társadalmi megítélést folytonosként kezeltük. A két becslés során a materializmus mércénk továbbra is szignifikáns negatív kapcsolatot mutatott a személyes jólléttel, 1 százalékos szignifikancia szint mellett. Az anyagi javak birtoklására vonatkozó társadalmi megítélés esetén is negatív kapcsolatot véltünk felfedezni. Az interakciós tényezőkre becsült paraméterek azonban nem tértek el szignifikánsan nullától, vagyis nem módosítja az anyagiasság-jóllét kapcsolatot az, ha az egyén úgy érzi, a környezete inkább az anyagi javak birtoklásán keresztül ítéli meg.

A negyedik regresszió esetében arra voltunk kíváncsiak, hogy a háztartás anyagi helyzete miként módosítja a materializmus-személyes jóllét kapcsolatot. A létrehozott változónk - anyagi helyzet (dummy) - az anyagi helyzet kontrollváltozóból került kialakításra, ahol az ötfokozatú skálán legmagasabb értéket válaszoló - nagyon jól megél(nek) belöle és félre is tud(nak) tenni-megfigyelésekhez egyet, míg a többi értékhez nullát rendeltünk. Ennél a tényezőváltozónál is az anyagiasság változónkkal hajtottuk végre az interakciót. Ahogy az első tábla negyedik regresszióhoz tartozó értékeinél láthatjuk, a jólétben élő válaszadók minden más tényezőt figyelmen kívül hagyva nagyobb elégedettségröl számoltak be, mint a mintánkban megfigyelhető átlagos elégedettség. Az eredményeink szerint a materializmus és személyes jóllét közötti kapcsola- tot nem módosítja az anyagi helyzet.

A fenti eredmények fényében azt mondhatjuk, hogy az anyagiasság és személyes jóllét közötti kapcsolatra megfogalmazott la hipotézisünket elfogadhatjuk, az anyagiasság és személyes jóllét között fordított kapcsolat figyelhető meg, amennyiben a személyes jóllétet az élettel való elégedettséggel közelítjük.

\section{Anyagiasság és önbecsülés kapcsolata The relationship between materialism and self-esteem}

A személyes jóllétet közelíteni szándékozó második változónk, az önbecsülés esetében az előzőekben már felvázolt vizsgálatokat ismételtük meg. A regressziós becslésekből származó eredmények a 2 . táblázatban találhatók.

A kontrollváltozók közül a nem, az egészségi állapot, és az anyagi helyzet esetében szignifikáns kapcsolatot találtunk. Érdekesség, hogy míg az utóbbi két ismérvnél a kapcsolat pozitívnak mutatkozott, addig a nőknél negatív kapcsolat volt megfigyelhető. Minden egyéb tényezőt változatlannak feltételezve a nők önbecsülése mintaátlag alatti.

Ami az anyagiasság-személyes jóllét kapcsolatot illeti, ugyanazokra az eredményekre jutottunk, mint az élettel való elégedettség esetében. Az anyagiasság negatív kapcsolatban van a mintaátlaghoz viszonyított önbecsüléssel. Tehát minél fontosabb szerepet töltenek be az anyagias értékek az egyén értékrendjében, annál kisebb a sokasághoz viszonyítva az önmagával való megelégedettsége. Az eredmények mind a négy regresszió esetében szignifikánsnak mutatkoztak. Az anyagi javak birtoklására vonatkozó társadalmi megítélés esetében szintén hasonló eredményekre jutottunk. Az interakciós tényezőkre becsült paraméterek nem tértek el szignifikánsan nullától, vagyis az anyagiasság-jóllét kapcsolatot nem módosítja az, ha az egyén úgy érzi, a környezete inkább az anyagi javak birtoklásán keresztül ítéli meg. Végül, ahogy a negyedik regresszió során kapott értékekből látható, a jólétben élő válaszadók nagyobb önbecsülésről számoltak be, mint a mintánkban megfigyelhető átlag, az anyagiasság és önbecsülés közötti kapcsolatot azonban nem módosítja az anyagi helyzet.

A 2. táblázatban látható eredmények fényében azt mondhatjuk, hogy az anyagiasság és személyes jóllét közötti kapcsolatra megfogalmazott $1 \mathrm{~b}$ hipotézisünket elfogadhatjuk, az anyagiasság és személyes jóllét között fordított a kapcsolat, amennyiben a személyes jóllétet az önbecsüléssel közelítjük. 
2. táblázat: Az anyagiasság és az önbecsülés kapcsolata

Table 2. The relationship between materialism and self-esteem

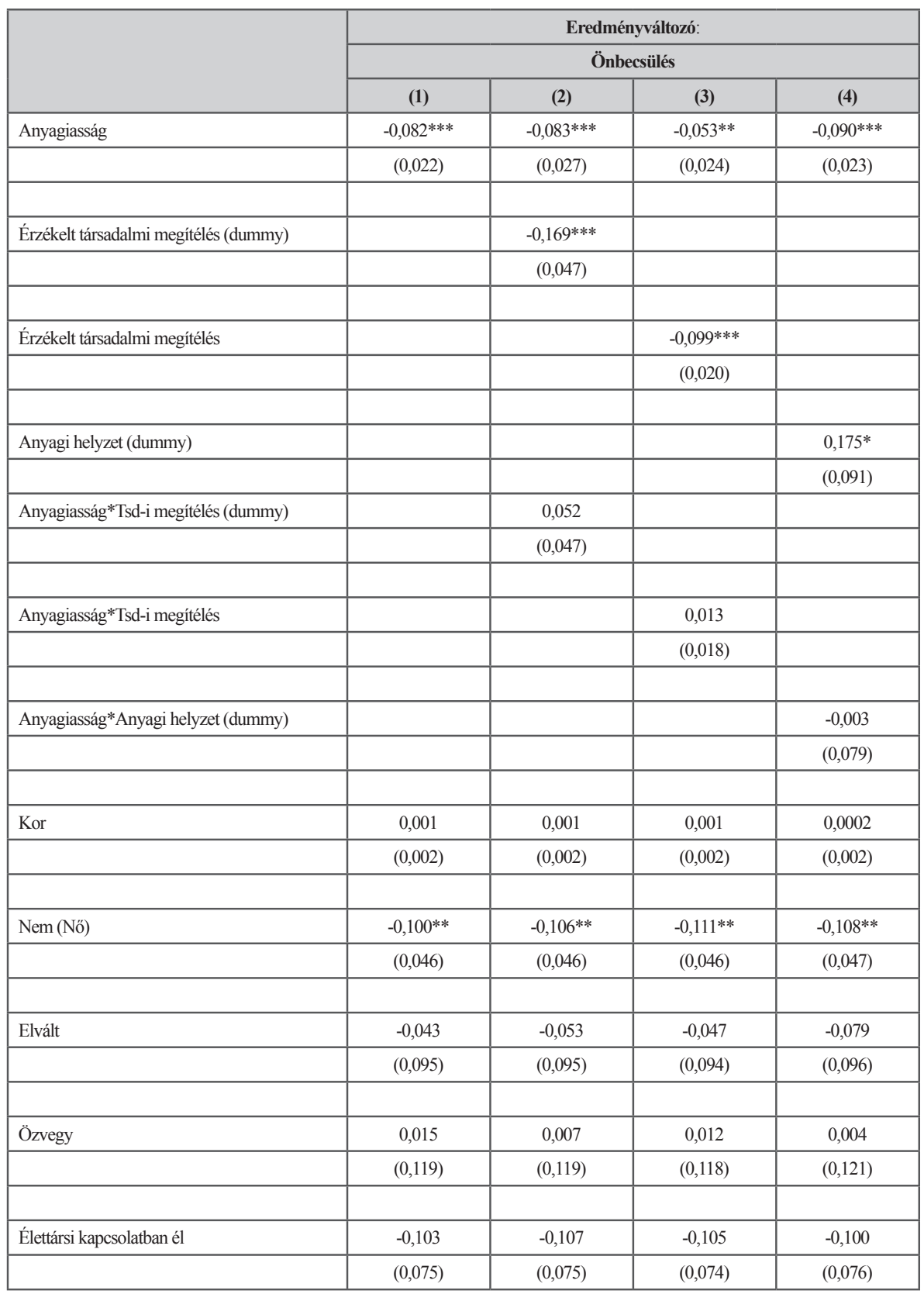




\begin{tabular}{|c|c|c|c|c|}
\hline & & Erec & ttozó: & \\
\hline & & & & \\
\hline & (1) & (2) & (3) & (4) \\
\hline Házas & $-0,014$ & $-0,012$ & $-0,006$ & 0,004 \\
\hline & $(0,071)$ & $(0,070)$ & $(0,070)$ & $(0,072)$ \\
\hline Egészségi állapota némiképp korlátozza az & $0,418^{* * *}$ & $0,435^{* * *}$ & $0,420^{* * *}$ & $0,463 * * *$ \\
\hline & $(0,130)$ & $(0,130)$ & $(0,129)$ & $(0,131)$ \\
\hline Teljesen egészséges & $0,702 * * *$ & $0,726^{* * * *}$ & $0,725^{* * *}$ & $0,791 * * *$ \\
\hline & $(0,129)$ & $(0,129)$ & $(0,128)$ & $(0,129)$ \\
\hline Néha arra se elég, hogy megéljenek belöle & 0,332 & 0,351 & 0,346 & \\
\hline & $(0,243)$ & $(0,243)$ & $(0,242)$ & \\
\hline Elegendö, hogy megéljenek, de félretenni & $0,446^{* *}$ & $0,463 * *$ & $0,451^{* *}$ & \\
\hline & $(0,227)$ & $(0,227)$ & $(0,226)$ & \\
\hline Megélnek, de keveset tudnak félretenni & $0,743^{* * *}$ & $0,755^{* * *}$ & $0,736^{* * *}$ & \\
\hline & $(0,229)$ & $(0,228)$ & $(0,227)$ & \\
\hline Nagyon jól megélnek, és félre is tudnak tenni & $0,782 * * *$ & $0,807 * * *$ & $0,805^{* * *}$ & \\
\hline & $(0,241)$ & $(0,240)$ & $(0,239)$ & \\
\hline Szakmunkásképző, szakiskola & $-0,065$ & $-0,062$ & $-0,060$ & $-0,002$ \\
\hline & $(0,074)$ & $(0,074)$ & $(0,074)$ & $(0,074)$ \\
\hline Szakközépiskolai érettségi & 0,028 & 0,024 & 0,031 & 0,093 \\
\hline & $(0,079)$ & $(0,079)$ & $(0,079)$ & $(0,080)$ \\
\hline Gimnáziumi érettségi & 0,034 & 0,023 & 0,024 & 0,139 \\
\hline & $(0,090)$ & $(0,089)$ & $(0,089)$ & $(0,089)$ \\
\hline Felsőfokú technikum/OKJ/FOKSZ & $-0,129$ & $-0,155$ & $-0,154$ & $-0,004$ \\
\hline & $(0,107)$ & $(0,107)$ & $(0,106)$ & $(0,107)$ \\
\hline Főiskolai diploma & $-0,016$ & $-0,029$ & $-0,033$ & 0,106 \\
\hline & $(0,097)$ & $(0,097)$ & $(0,097)$ & $(0,097)$ \\
\hline
\end{tabular}




\begin{tabular}{|c|c|c|c|c|}
\hline & \multicolumn{4}{|c|}{ Eredményváltozó: } \\
\hline & \multicolumn{4}{|c|}{ Önbecsülés } \\
\hline & (1) & (2) & (3) & (4) \\
\hline \multirow[t]{2}{*}{ Egyetemi diploma } & $-0,097$ & $-0,130$ & $-0,119$ & 0,031 \\
\hline & $(0,130)$ & $(0,130)$ & $(0,129)$ & $(0,131)$ \\
\hline \multirow[t]{2}{*}{ Konstans } & $-0,459 *$ & $-0,416$ & $-0,500^{*}$ & $-0,011$ \\
\hline & $(0,259)$ & $(0,258)$ & $(0,257)$ & $(0,158)$ \\
\hline Megfigyelések száma & 1.819 & 1.819 & 1.819 & 1.819 \\
\hline $\mathrm{R} 2$ & 0,079 & 0,088 & 0,094 & 0,056 \\
\hline Korrigált R2 & 0,070 & 0,077 & 0,084 & 0,047 \\
\hline Becslés standard hibája & $0,940(\mathrm{df}=1799)$ & $0,936(\mathrm{df}=1797)$ & $0,933(\mathrm{df}=1797)$ & $0,951(\mathrm{df}=1801)$ \\
\hline F-próba & $\begin{array}{c}8,153 * * *(\mathrm{df}= \\
19 ; 1799)\end{array}$ & $\begin{array}{c}8,269 * * *(\mathrm{df}= \\
21 ; 1797)\end{array}$ & $\begin{array}{c}8,904 * * *(\mathrm{df}= \\
21 ; 1797)\end{array}$ & $\begin{array}{c}6,240 * * *(\mathrm{df}= \\
17 ; 1801)\end{array}$ \\
\hline
\end{tabular}

Megjegyzés: ${ }^{*} p<0,1 ; * * p<0,05 ; * * * p<0,01$; Zárójelben a t-próba értékek találhatók, Függő változó: ötfokozatú skálán mért önbecsülésre adott válasz és a mintában megfigyelhetö átlagos önbecsülés különbsége.

Forrás: saját szerkesztés

\section{Anyagiasság és az anyagi lehetőségek terïletén érzékelt hátrány kapcsolata The relationship between materialism and the perceived lack of financial opportunities}

A vizsgálat utolsó részében arra voltunk kíváncsiak, hogy az anyagiasság milyen kapcsolatban van az anyagi lehetőségek területén érzékelt hátránnyal. Eredményváltozóként a már korábban bemutatott anyagi hátrány ismérvet vettük figyelembe és arra kerestük a választ, hogy a különböző anyagi helyzetben lévő válaszadók - itt az anyagi helyzet (dummy) változót alkalmaztuk ismét - esetében miként alakul az anyagiasság és az eredményváltozó közötti kapcsolat. Ehhez az anyagi helyzet bináris változót vontuk be a regresszióba és megvizsgáltuk az anyagiasság és az anyagi helyzet közötti kölcsönhatást is. A OLS-regressziót követően kapott eredményeket a 3. táblázat tartalmazza. 
3. táblázat: Az anyagiasság és az érzékelt anyagi hátrány kapcsolata

Table 3. The relationship between materialism and the perceived lack of financial opportunities

\begin{tabular}{|c|c|}
\hline & Eredményváltozó \\
\hline & Anyagi hátrány* \\
\hline Anyagiasság & 0,022 \\
\hline & $(0,022)$ \\
\hline Anyagi helyzet (dummy) & $-0,362 * * *$ \\
\hline & $(0,087)$ \\
\hline Anyagiasság*Anyagi helyzet (dummy) & $-0,009$ \\
\hline & $(0,075)$ \\
\hline Kor & $-0,005^{* * *}$ \\
\hline & $(0,002)$ \\
\hline Nem (nö) & $-0,027$ \\
\hline & $(0,044)$ \\
\hline Elvált & $-0,001$ \\
\hline & $(0,091)$ \\
\hline Özvegy & $-0,240^{* *}$ \\
\hline & $(0,114)$ \\
\hline Élettársi kapcsolatban él & $-0,091$ \\
\hline & $(0,072)$ \\
\hline Házas & $-0,271 * * *$ \\
\hline & $(0,068)$ \\
\hline $\begin{array}{l}\text { Egészségi állapota némiképp korlátozza az } \\
\text { életvitelben }\end{array}$ & $0,263 * *$ \\
\hline & $(0,125)$ \\
\hline Teljesen egészséges & $0,246 * *$ \\
\hline & $(0,123)$ \\
\hline Szakmunkásképző, szakiskola & 0,020 \\
\hline & $(0,071)$ \\
\hline Szakközépiskolai érettségi & $-0,142^{*}$ \\
\hline & $(0,075)$ \\
\hline
\end{tabular}




\begin{tabular}{|l|c|}
\hline & Eredményváltozó \\
\cline { 2 - 2 } & Anyagi hátrány* \\
\hline Gimnáziumi érettségi & $-0,145^{*}$ \\
\hline & $(0,085)$ \\
\hline Felsöfokú technikum/OKJ/FOKSZ & $-0,325^{* * *}$ \\
\hline & $(0,101)$ \\
\hline & \\
\hline Föiskolai diploma & $-0,143$ \\
\hline & $(0,092)$ \\
\hline & \\
\hline Egyetemi diploma & $-0,241^{*}$ \\
\hline & $(0,124)$ \\
\hline & \\
\hline Konstans & $0,701 * * *$ \\
\hline & $(0,150)$ \\
\hline & \\
\hline Megfigyelések száma & 1.819 \\
\hline R2 & 0,067 \\
\hline Korrigált R2 & 0,059 \\
\hline Becslés standard hibája & $0,903(\mathrm{df}=1801)$ \\
\hline F-próba & $7,646^{* * * *}(\mathrm{df}=17 ; 1801)$ \\
\hline
\end{tabular}

Megjegyzés: ${ }^{*} p<0,1 ; * * p<0,05 ; * * * p<0,01$; Zárójelben a t-próba értékek találhatók, Függő változó: ötfokozatú skálán mért önbecsülésre adott válasz és a mintában megfigyelhetö átlagos önbecsülés különbsége.

Forrás: saját szerkesztés

Látható, hogy a jobb anyagi helyzetről beszámoló egyének kevésbé érzékelik az anyagi lehetőségek hiányát, a materializmus és az anyagi lehetőségek területén érzékelt hátrány közötti kapcsolat esetében azonban nem figyelhető meg különbség a két csoport között. Sőt az anyagiasság látszólag nincs kapcsolatban az anyagi lehetőségek terén érzékelt hátránnyal.
A vizsgálat utolsó részében kapott eredmények arra engednek következtetni, hogy az anyagiasság nincs kapcsolatban az anyagi lehetőségek terén érzékelt hátránnyal, sem anyagi jólét, sem anyagi nélkülözés mellett. A $2 a$ és $2 b$ hipotéziseket így elvetettük. 


\section{A KUTATÁS KORLÁTAI LIMITATIONS}

A kutatás során végig azzal a feltételezéssel éltünk, hogy az anyagiasság, mint gondolkodásmód, megragadható a gazdagságnak és a pénznek tulajdonított relatív fontossággal. Habár jogos feltételezésnek tủnik, hogy az anyagelvủ életstílusba beletartozik a gazdagság és pénz priorizálása, ugyanakkor nem csak és kizárólag ez tartozik bele. A materializmus a jólét mellett többek között a birtoklásra, imázsra-megjelenésre, valamint társadalmi státuszra irányuló érték (Debreceni, 2018). A kutatást érdemes lenne megismételni egy szofisztikáltabb materializmusmérce alkalmazásával, mely az anyagiasságot pontosabban képes megragadni. Emellett érdemes lenne megvizsgálni, hogy a materializmus jellemvonást meghatározó háttértényezők közül, melyik milyen kapcsolatban áll a személyes jólléttel.

Fontos megjegyezni, hogy az adatok keresztmetszeti jellege nem teszi lehetővé, hogy ok-okozati összefüggéseket tárjunk fel. Ebböl kifolyólag csak logikai úton következtethetünk arra, hogy a materialista beállítottság az ok, míg a személyes jóllét az okozat szerepét tölti be. A kapott eredmények értelmezése során azonban nem szabad kizárnunk annak eshetőségét, hogy a vizsgált dimenziók között fordított a kauzalitás. Elképzelhető, hogy az egyének azért válnak anyagiassá, mert életükkel kevésbé elégedettek, vagy mert önbecsülésük kisebb. A vizsgált tényezők közötti ok-okozati összefüggést longitudinális vizsgálatok keretében lehetne feltárni.

\section{ZÁRÓ GONDOLATOK CONCLUDING REMARKS}

A dolgozat abba az 1980-as évek közepe óta tartó tudományos diskurzusba kapcsolódik be, mely az anyagiasság és az egyén személyes jólléte közötti kapcsolatot próbálja feltárni. Az egyre inkább anyagelvü szemlélet mentén múködő világunkban fontos annak megértése, hogy valójában milyen hatással van az emberek személyes jóllétére a materialista célok elötérbe helyezése.

Eredményeink alapján a korábbi szakirodalommal konzisztens következtetésekre jutottunk (Dittmar et al., 2014; Kasser, 2016; Debreceni, 2018; Moldes és $\mathrm{Ku}, 2020$ ). Mind az élettel való elégedettség, mind az önbecsülés esetében azt kaptuk, hogy az anyagiasság negatív kapcsolatban áll a személyes jólléttel. A kapcsolat iránya változatlan maradt azokban az esetekben is, amikor az érzékelt társadalmi megítélést figyelembe vettük a kontrollváltozók mellett. Megvizsgáltuk továbbá, hogy a különböző anyagi helyzetben lévő egyének esetében az anyagiasság milyen kapcsolatban van az anyagi lehetőségek területén érzékelt hátránnyal. A vizsgálat ezen részénél nem találtunk szignifikáns eredményeket.

A fenti eredmények fényében tehát azt mondhatjuk, hogy a materialista értékek elötérbe helyezése nem tekinthető racionálisnak, mivel alacsonyabb élettel való elégedettséggel, valamint önbecsüléssel párosul. Természetesen a fejlett nyugati társadalmak anyagiassá válásának kérdése túlmutat a személyes jólléttel való kapcsolaton. Az anyagias célok előtérbe helyezésének a mérséklése, nem csak egyéni, hanem környezeti és társadalmi szempontokból is kívánatos lehet. 


\section{HIVATKOZÁSOK REFERENCES}

Belk, R. W. (1984). Three Scales to Measure Constructs Related to Materialism: Reliability, Validity, and Relationships to Measure of Happiness, Advances in Consumer Research, 11, 291-7

Belk, R. W. (1988). Possessions and the Extended Self, Journal of Consumer Research, 15(2), 139-68 DOI: $10.1086 / 209154$.

Brown, K. W. and Kasser, T. (2005). Are psychological and ecological well-being compatible? The role of values, mindfulness, and lifestyle. Social Indicators Research, 74(2), 349-68 DOI: 10.1007/s11205-0048207-8.

Debreceni J. (2018). Merre tart az anyagiasság-kutatás? Az elmúlt nyolc év meghatározó kutatási eredményeinek összefoglalása. (What are the tendencies in materialism studies? A review on the most relevant research findings since 2010. Józsa L.- Korcsmáros E. - Seres Huszárik E. (szerk.) A hatékony marketing: EMOK 2018 Nemzetközi Tudományos Konferencia konferenciakötete. Selye János Egyetem, Komárom, 148-159.

Deci, E. L. and Ryan, R. M. (2000). The "what" and "why" of goal pursuits: Human needs and the self-determination of behavior. Psychological Inquiry, 4, 227-68 DOI: 10.1207/S15327965PLI1104_01.

Dittmar, H., Kapur, P. (2011). Consumerism and Well-Being in India and the UK: Identity Projection and Emotion Regulation as Underlying Psychological Processes. Psychological Studies. 56(1), 71-85. DOI: 10.1007/s12646-011-0065-2.

Dittmar, H.. Bond, R., Hurst, M., Kasser, T. (2014). The relationship between materialism and personal well-being: A meta-analysis. Journal of Personality and Social Psychology, 107(5), 879-924. DOI: 10.1037/a0037409.

Hellevik, O. (2003). Economy, Values and Happiness in Norway. Journal of Happiness Studies, 4, 243-83 DOI: 10.1023/A:1026232018534.

Hornyák M., Kehl D., Kruzslicz F., Szücs K. (2014). Az életstílus-alapú szegmentáció módszertani kihívásai. Marketing \& Menedzsment, 48 II. különszám, 69-82

Kasser, T. (2016). Materialistic values and goals. Annual Review of Psychology, 67(1), 489-514 DOI: 10.1146/annurev-psych-122414-033344.

Kasser, T., Ryan, R. M. (1993), „A Dark Side of the American Dream: Correlates of Financial Success as a Central Life Aspiration", Journal of Personality and Social Psychology. 65(2), 410-422 DOI: 10.1037/0022-3514.65.2.410.

Kasser, T., Ryan, R. M., Zax, M., Sameroff, A. J. (1995). The Relations of Maternal and Social Environments to Late Adolescents' Materialistic and Prosocial Values. Developmental Psychology. 31(6), 907-14 DOI: 10.1037/0012-1649.31.6.907.
Kasser, T., Rosenblum, K., Sameroff, A. J., Deci, E. L., Niemiec, C. P., Ryan, R. M., Árnadóttir, O., Bond, R., Dittmar, H., Dungan, N., Hawks, S. (2014). Changes in materialism, changes in psychological well-being: Evidence from three longitudinal studies and an intervention experiment, Motivation and Emotion, 38(1), 1-22 DOI: 10.1007/s11031-0139371-4.

Kelemen R. - Kincses Á. (2015). A jóllét magyarországi indikátorrendszerének elméleti alapjai. Gazdálkodás, 59(3), 220-36

Kim, Y., Kasser, T., Lee, H. (2003). Self-concept, aspirations, and weil-being in South Korea and the United States. Journal of Social Psychology, 143(3), 27790 DOI: 10.1080/00224540309598445.

Lee, M. S. W., Ahn, C. S. Y. (2016). Anti-consumption, Materialism, and Consumer Well-being. Journal of Consumer Affairs. 50(1), 18-47 DOI: 10.1111/ joca. 12089.

Moldes, O., Ku, L. (2020). Materialistic cues makes us miserable: A meta-analysis of the experimental evidence for the effects of materialism on individual and societal well-being, Psychology and Marketing, 37(10), 1396-419 DOI: 10.1002/mar.21387.

Nepomuceno, M. V., Laroche, M. (2015). The impact of materialism and anti-consumption lifestyles on personal d.ebt and account balances. Journal of Business Research,. 68(3), 654-64 DOI: 10.1016/j. jbusres.2014.08.006.

Richins, M. L., Dawson, S. (1992). A Consumer Values Orientation for Materialism and Its Measurement: Scale Development and Validation. Journal of Consumer Research, 19(3), 303-16 DOI: 10.1086/209304.

Rindfleisch, A., Burroughs, J. E., Denton, F. (1997). Family structure, materialism, and compulsive consumption. Journal of Consumer Research, 23(4), 312-25 DOI: 10.1086/209486.

Schor, J. (1999). What's Wrong with Consumer Society? Competitive Spending and the "New Consumerism". Rosenblatt, R. (ed.). Consuming desires: consumption, culture, and the pursuit of happiness, Washington, DC: Island Press

Sheldon, K. M., Kasser, T. (2008). Psychological threat and extrinsic goal striving. Motivation and Emotion, 32(1), 37-45 DOI: 10.1007/s11031-008-9081-5.

Twenge, J. M., Gentile, B., DeWall, C. N., Ma, D., Lacefield, K., Schurtz, D. R. (2010). Birth cohort increases in psychopathology among young Americans, 1938-2007: A cross-temporal meta-analysis of the MMPI. Clinical Psychology Review, 30(2), 145-54 DOI: 10.1016/j.cpr.2009.10.005.

Wang, R., Liu, H., Jiang, J., Song, Y. (2017). Will materialism lead to happiness? A longitudinal analysis of the mediating role of psychological needs satisfaction. Personality and Individual Differences, 105, 312-7 DOI: 10.1016/j.paid.2016.10.014. 
Erdős Sándor, PhD hallgató erdos.sandor@ktk.pte.hu Pécsi Tudományegyetem Közgazdaságtudományi Kar

\section{THE RELATIONSHIP BETWEEN MATERIALISM AND WELL-BEING: A DRAWBACK OF WESTERN CONSUMER SOCIETY}

\section{THE AIMS OF THE PAPER}

The study joins in the academic discussion that examines the relationship between materialism and personal well-being since the mid 1980s. The aim of the study is to investigate the nature of the relationship between materialism as a mindset and personal well-being. Furthermore it wishes to identify the drawbacks of western consumer society.

\section{METHODOLOGY}

Our analysis was conducted on a sample from a questionnaire survey with 1819 observations, that is concerning demographic characteristics nationally representative. In case of the variables included in our analysis the effect of potential biases arising from questionnaire surveys were managed. We measured the materialism variable, that played a central role in our analysis, as the relative position of wealth and money within the personal value system of respondents, while the life satisfaction and self-esteem variables were calculated as the difference from the sample average. We used OLS-regression for testing the relationship between variables.

\section{MOST IMPORTANT RESULTS}

The individuals who indicated wealth and money as important priorities in their value systems were generally more dissatisfied with their lives and had lower self-esteem compared to the respondents who scored lower on the materialism scale. This correlation was found to be irrespective of their actual financial status. Furthermore, irrespective of whether they felt being judged by their environment based on their possession of material goods or not. We found no significant relationship between materialism and the perceived lack of financial opportunities.

\section{RECOMMENDATIONS}

Prioritizing materialistic values seems irrational as it can correlate to a decreased personal well-being. Although objective and subjective, as well as social and environmental factors form part of well-being, according to our results being materialistic, and following a consumer culture that emphasizes materialistic values could lead to problems at the level of the individual.

Keywords: materialism, well-being, personal well-being, life satisfaction, self-esteem 